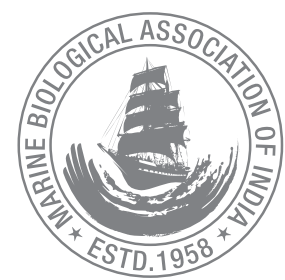

\title{
Taxonomy of the Ocean triggerfish, Canthidermis maculata (Tetradontiformes, Balistidae) from the Indian coast
}

\author{
Satish Sahayak, K. K. Joshi ${ }^{*_{1}}$ and V. Sriramachandramurty ${ }^{1}$ \\ Programme Manager, Ornamental Fish Division, Marine Products Export Development Authority, Chennai - 600 040, India \\ ${ }^{1}$ Central Marine Fisheries Research Institute, Kochi- 682 018, Kerala, India. \\ *Correspondence e-mail: joshyguru@gmail.com
}

\begin{abstract}
The collection and analysis of fishes of the genus Canthidermis done during 2000-2002. The results revealed high intraspecific colour variation among the samples collected from different localities. Canthidermis maculata from Indian seas is redescribed with new characters and examined the status of synonyms of the species. The regression analysis using data of various morphometric measurements on standard lengths revealed a low relationship and significant, suggesting that $C$. maculata showed high degree of variability in morphological characters. The examination reveals that C. willughbeii (Lay and Bennett, 1839), C. rotundatus (Proce, 1822), C. villosus Fedoryako, 1981 are junior synonym of C. maculata (Bloch, 1786).
\end{abstract}

Keywords: Triggerfishes, Canthidermis maculata, colour variation, Synonym, India.

\section{Introduction}

Triggerfishes (Family: Balistidae) occupy diverse habitats such as coral reefs, rocky areas, seaweed beds and under floating objects in the open ocean regions (Fedoryako, 1981). Balistids are brightly coloured fishes and many species are distinguished primarily on the basis of colour patterns (Smith and Heemstra, 1986). Most of the species grow up to about $30 \mathrm{~cm}$ length, while some reach more than half a meter in length (Day, 1878). Taxonomic information on this family is meagre and from a few geographical regions that too outside India (Bleeker, 1866; Fraser-Brunner, 1935 and Matsuura, 1980). These fishes do not form major fishery anywhere along their distributional range. As the major interest in research has been on the commercially important fishes, no significant research effort has been paid to any aspect of these fishes (Abdussamad et al., 2009). The recent trend in exploitation for human consumption and export and the fast increasing demand for these fishes in live condition for aquarium purpose warrant knowledge on taxonomy, distribution in space and time, biological characteristics and stock size to enable formulating strategies for sustaining yields and for addressing the issues of biodiversity conservation.

In Indian seas, nine genera and 33 species of Triggerfishes were recorded. Among these, genus Canthidermis was erected by Swainson with type species Canthidermis maculata during 1839. The species in this genus was mainly described on the basis of one or few specimens and hence did not taken into the account of possible intra specific variation in growth. This resulted in the inconsistencies in nomenclature and confusion in synonymies. The present study on the genus Canthidermis of family Balistidae is an attempt to provide adequate description of species from several locations at different 
length groups to sort out the issues related to nomenclature and synonymies.

\section{Material and methods}

The collection of specimens from Vizhinjam and examination of specimens in the Museum collections of Zoological Survey of India (ZSI), Kolkata and those in the reference collections of Museum of the Central Marine Fisheries Research Institute (CMFRI) at Cochin and Mandapam were done during 20002002. Soon after collection, the fresh colour and pigmentation of the specimens were recorded at the landing centre and photographs were taken. The specimens were then injected with $5 \%$ formalin and brought to the laboratory in containers filled with $5 \%$ formalin for detailed studies. In taking the meristic and morphometric data, the methodology of Hubbs and Lagler (1958) and Matsuura, 1980 was followed; all the linear measurements were made in the median longitudinal axis. Examination of the nasal apertures and the counts of lateral line scales, arrangement and morphology of the scales on the cheek, body, abdomen, caudal peduncle and fin rays counts were made under a binocular stereo zoom microscope.

The scales of on cheek, body, abdomen and caudal peduncle on specific area were selected and examined under stereo zoom microscope (magnification 5x-20x) to compare the arrangement, shape and morphology of the scale. After the initial study, scales with skin were dissected out and boiled in $5 \% \mathrm{KOH}$ solution for 5 minutes to separate the scales from tissue to observe the shape and arrangement of protuberances. The scales were first examined under the stereo zoom microscope and later were treated in $1 \%$ Osmium Tetraoxide and coated with gold in the gold spatter for observing under Scanning Electron Microscope at CMFRI, Kochi. The observations were made in the Hitachi $\mathrm{H} 600$ Electron Microscope having an H6010-A SEM attachment with magnification of $100 x$ and $200 x$.

The relationship between certain body lengths and standard length and between certain dimensions in the head and head length were calculated after ascertaining the type of relationship through a scatter diagram, following the least squares method (Snedeor and Cochran, 1967). The results are presented in the figures and the calculated values of slope and elevation, along with the value of the coefficient of determination $\left(R^{2}\right)$ are shown in the figures for each species. Certain body proportions for each species, are expressed as percentage of standard length and certain proportions in the head expressed as percentage of head (head length) are given in the descriptions; the means are given in parentheses following the range for each proportion, as such studies facilitate comparing and differentiating between closely resembling species of a genus (Abraham et al., 2011) and comparison of the stocks of the same species from different localities (Lachner and Jenkins, 1971). A study of this nature assumes greater importance, since the body proportions are known to vary with growth i.e., the rate of growth of a body part changes with increase in length. Understanding such variations in growth (allometric growth) will help in understanding the intraspecific variations in each species. The International Code of Zoological Nomenclature was constantly consulted; when cited in the text it is referred to as Code.

\section{Results}

Genus Canthidermis Swainson, 1839

(Type species: Canthidermis oculatus Gray, 1830)

\section{Diagnosis}

Anterior nasal funnel shaped, groove present. Scales on cheek square shaped at the anterior, posteriorly rhomboid with some triangular scale arranged horizontally with fleshy row in between. Body scales with ridges and a large ridge at the anterior middle. Caudal peduncle, longer than deep, laterally elliptical, 8-10 rows of scales with blunt ridges at the centre, arranged horizontally. Ventral flap absent and caudal fin double lunate.

\section{Canthidermis maculata (Bloch, 1786)}

(Fig.1 a and b)

Balistes maculatus Bloch, 1786, p.25, pl. 151.

Balistes maculatus Day, 1878, p.687.

Canthidermis rotundatus (Jones and Kumaran, 1980), p. 665, fig.566.

Material examined: 23 specimens from Vizhinjam, (12 females, 11 males) ranging from 220 to $369 \mathrm{~mm} \mathrm{TL}$, one specimen from Bay of Bengal, ZSI (Reg. No. 11882) of length of $162 \mathrm{~mm} \mathrm{TL}$, (Fig. $1 \mathrm{f}), 2$ specimens, from Madras coast, ZSI (Reg. No. 13748, 13750) of lengths 113, $98 \mathrm{~mm} \mathrm{TL,} \mathrm{(Fig.1}$ d-e), 2 specimens, from Sand Head, ZSI (Reg. No. 8164, 8165) of lengths $70-86 \mathrm{~mm} \mathrm{TL}$, (Fig. $1 \mathrm{c}$ ).

Description: D. III, ii, 21-26; P. i, 13 -14; ventral spines $0-12$; A. i, $18-22$; C. ii, 10; gill rakers 19-23; number of scales from origin of second dorsal to base of anal 16-20; lateral line scales 48 -70; scales round the caudal peduncle 11-15.

As percent of standard length: Depth 35.56-43.53 (39.10); head 30.51-34.83 (32.16); snout 18.01-20.63 (19.17); predorsal length (I) 26.79-33.71 (30.96); predorsal length (II) 59.05-64.25 (61.59); preanal length 62.0-67.20 (64.51); postdorsal length (I) 46.63-54.78 (50.83); post dorsal length (II) 8.11-15.27 (11.22); base of first dorsal 15.60-22.70 (18.63); base of second dorsal 22.52-34.39 (27.38); base of 

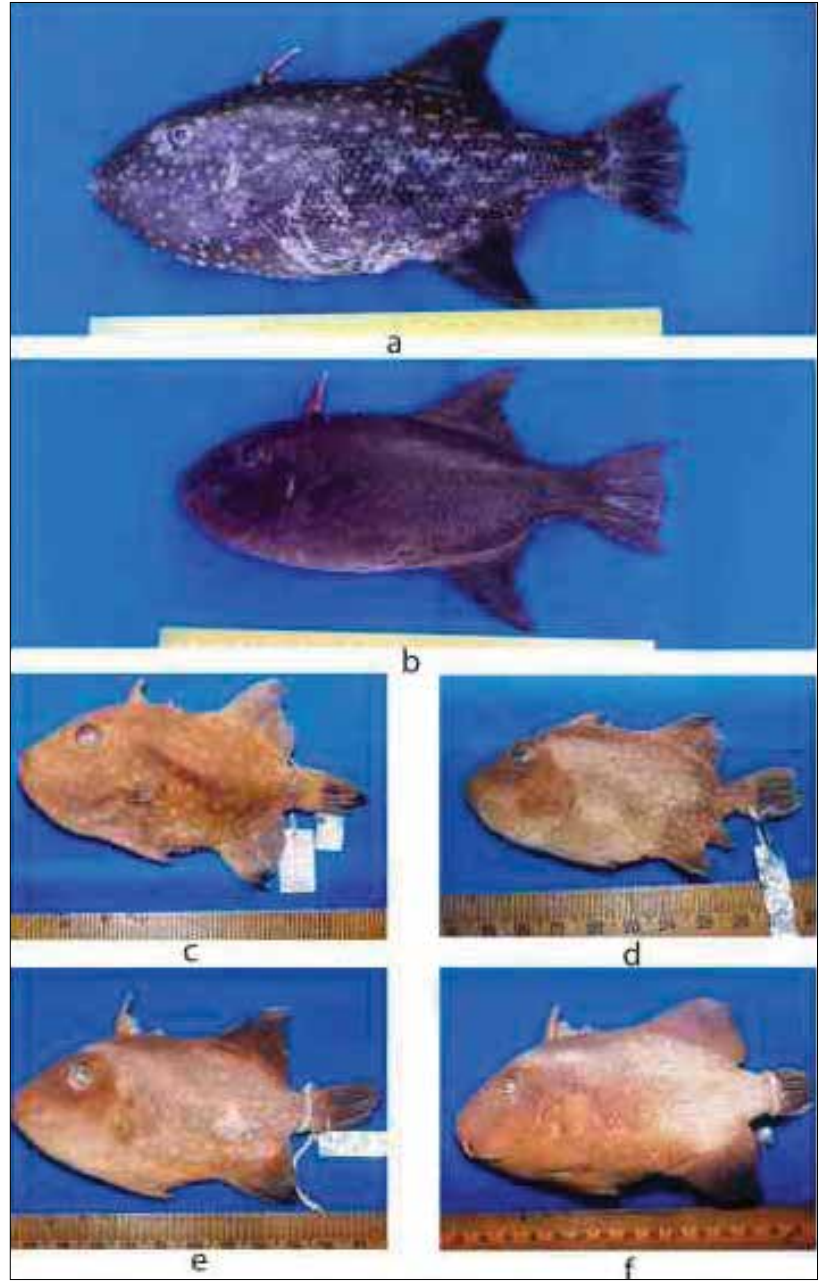

Fig. 1. Canthidermis maculata (Bloch, 1786) from (a) Vizhinjam, 336 mm TL, (b) Vizhinnjam 317 mm TL, (c) Sand head ZSI- 8165, 86 mm TL, (d) Madras ZSI-13748, 98 mm TL, (e) Madras ZSI- 13750, 113 mm $\mathrm{TL}$, (f) Bay of Bengal ZSI-11882 mm TL.

anal 20.26-29.10 (25.62); second dorsal 22.92-29.41 (25.98); anal 22.22-28.49 (25.33); pectoral 9.91-12.94 (10.78); caudal peduncle 10.69-12.70 (11.55). The regressions of different body dimensions on standard length are given in Fig. 2 .

As percent of head: Head height 96.63-114.04 (105.47); head width 40.32-60.0 (53.38); orbit 17.65-21.95 (19.75); interorbital 37.08-45.61 (41.10); postorbital 16.92-24.19 (20.53). The regressions of different head dimensions on head are given in Fig. 2.

Body elongated, head profile convex with a prominent chin; lips broad at centre narrows at edges. Interorbital convex, groove equal to eye diameter, narrow, deep anteriorly, broader posteriorly, connected to nasal depression by narrow groove. First dorsal spine pointed, anteriorly with large spinules on tip, compressed and smooth laterally. Third spine $1 / 4$ the length of first spine. Nostrils placed in a shallow

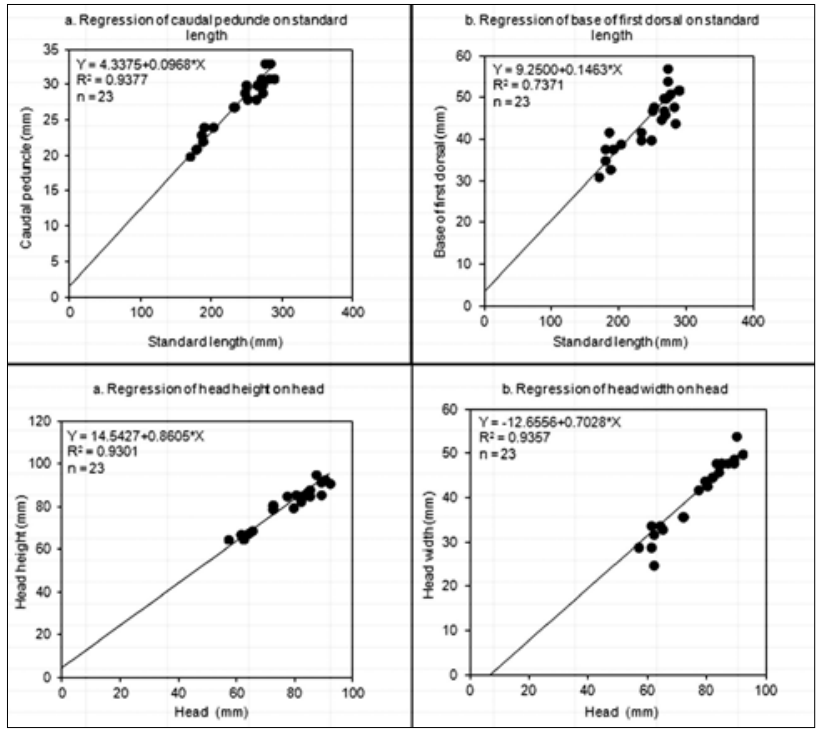

Fig. 2. Regression of different body dimensions on standard length and head dimensions on head length in Canthidermis maculata from south West coast of India.

depression with blunt round protuberances bordering the depression (Fig. 3a). Teeth rectangular with a conical edges (Fig. 3b). Scales above the base of pectoral absent. The gill rakers short and do not project above the edge of the branchial arch, the tip is pointed (Fig. 3c). Second dorsal and anal fins highly elevated anteriorly and short posteriorly; pectoral fin rounded.

Scales on cheek have round protuberances, ridges arranged in vertical rows (Fig. 3d \& Fig.4a). Body scale with large ridge at the anterior middle (narrow posteriorly) and with many ridges and round protuberances. (Fig.3e \& Fig. $4 \mathrm{~b}$ ). The ultra structure of the anterior margin of the body scale shows round depressions and a network of fibres (Fig. $4 \mathrm{e}-\mathrm{g}$ ) and the posterior margin has blunt round protuberances (Fig. $4 \mathrm{~h}-\mathrm{j}$ ). Scales on abdomen rectangular to rhomboid in shape with many ridges and round protuberances arranged in 3-6 oblique rows (Fig. 3 f \& Fig. 4c). Scales on caudal peduncle with ridge (tapering towards posterior and pointed) at the anterior, middle and round protuberances arranged in horizontal rows (Fig. $3 g$ \& Fig. 4d).

Ventral flap is reduced. The ventral spines are modified into a single row of modified scales present at the ventral side and each scale has many spines directed backwards giving a comb like appearance (Fig. 3h). Pelvic spine is movable, short, flat, thick and blunt, with small, blunt minute protuberance.

Colour: The whole fish is dark brownish black. Three types of colour variation i.e. body brownish black with dash like white spots, brownish black with white round spots spread all over the body and brownish black light brown ventrally. 

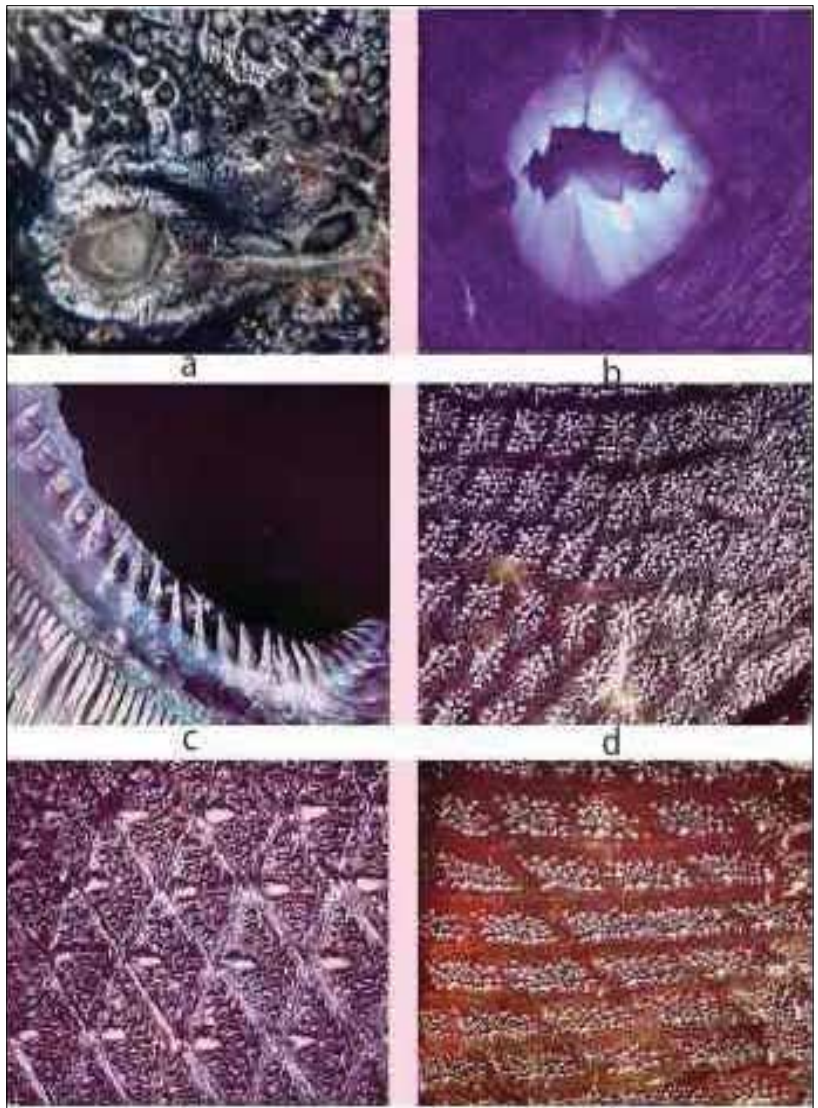

e

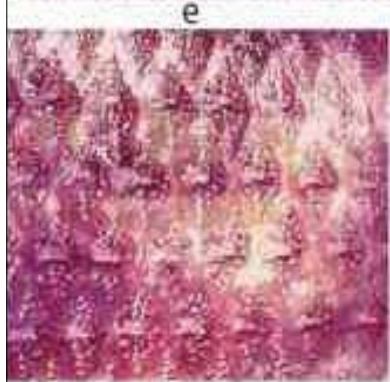

g
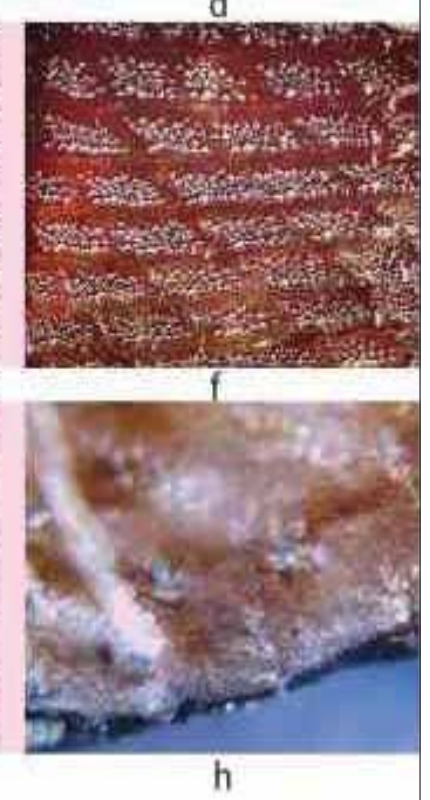

Fig. 3. Canthidermis maculata (Bloch, 1786), (a) Nasal apertures, (b) Teeth, (c) Gill rakers, (d) Scales on cheek, (e) Body scales, (f) Scales of abdomen, (g) Scales on caudal peduncle, (h) Ventral spines.

Colour of the preserved specimens: Formalin preserved specimens have dark brown with white spots, in some cases it is without spots. Alcohol preserved specimens have light brown colour.

Distribution: India, Japan, Gulf of Mexico, Florida, West Indies, Taiwan.

\section{Discussion}

According to Fedoryako (1981), five species of Canthidermis has been reported from the Pacific and Indian Oceans. $C$. willughbeii (Lay and Bennett, 1839), C. maculata (Bloch,

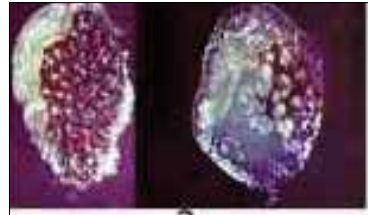

a
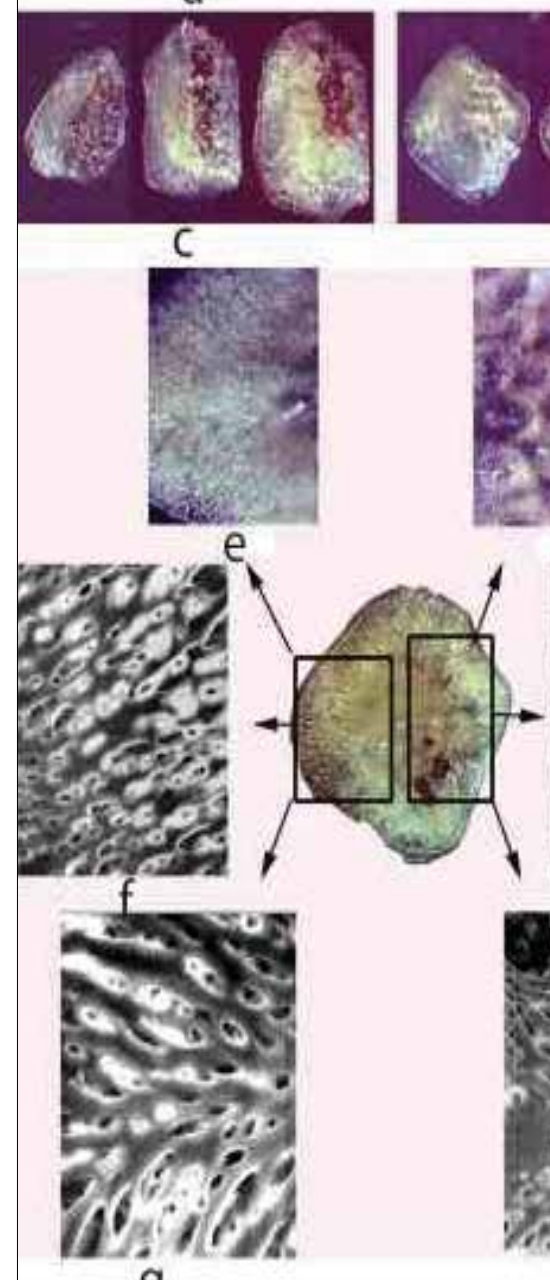

g

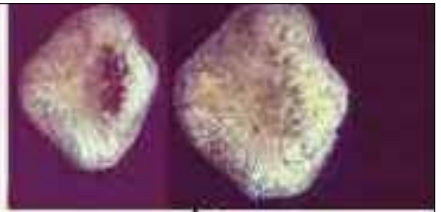

b

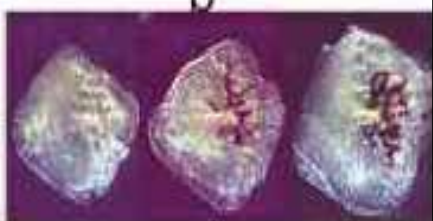

d

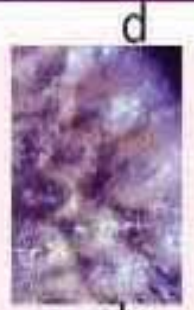

h
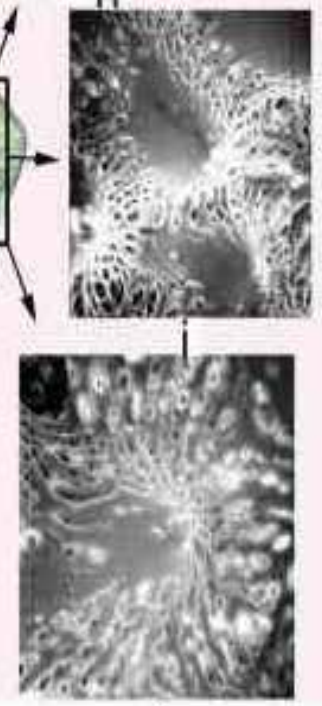

j

Fig. 4. Canthidermis maculata (Bloch, 1786), (a) Scales of cheek, (b) Body scales, (c) Scales of abdomen, (d) Scales of caudal peduncle, (e-g) Anterior margin of body scale 40x, 100x, 200x, (h-j) Posterior margin of body scale 40x, 100x, 200x

1786), C. rotundatus (Proce, 1822), C. sufflamen (Mitchill, 1815), and C. villosus (new) from Gulf of Aden. Fedoryako (1981) observed that C. villosus and C. rotundatus have same number of fin rays, gill rakers and armature of trunk scales. He indicated the differences as presence of branched dermal protuberances on scales, relatively smaller number of transverse rows of trunk scales, different length/depth ratio of the caudal peduncle and colouration of body and fins.

In case of $C$. maculata, the author has mentioned that the number of rays of second dorsal and anal fins differs slightly in the limits of variability and these fins are shorter compared 
to Moore (1967). It differs from C. rotundatus and C. villosus due to smaller number of fin rays and gill rakers, a greater number of small spinules on the trunk scales and mottled body colouration. C. rotundatus is different from C. maculata in scale armature on the trunk, number of fin rays and gill rakers. But larger specimens of $C$. rotundata and $C$. maculata has a longer second dorsal fin, a taller anal and pre-anal distance was less in former. But $C$. rotundatus was similar to $C$. villosus and $C$. sufflamen except that the latter has a greater number of transverse rows of scales, body depth and height of second dorsal and anal fins in comparison to C. maculata. The fin ray counts of all the species are given in the Table 1.

Table 1. Comparison of fin ray counts in different species of Canthidermis

\begin{tabular}{lllll}
\hline & Second dorsal & Anal & Pectoral & Standard length $(\mathrm{mm})$ \\
\hline C. maculata & $23-26$ & $21-23$ & $13-15$ & $50-100$ \\
\hline C. willughbeii & $23-24$ & $21-22$ & $13-14$ & $90-131$ \\
\hline C. rotundatus & $25-27$ & $22-23$ & $14-16$ & $39-111$ \\
\hline C. villosus & $24-26$ & $22-23$ & $14-15$ & $71.7-177.7$ \\
\hline C. sufflamen & $23-25$ & $20-22$ & $13-15$ & $20-300$ (Moore, 1967)
\end{tabular}

Berry and Baldwin (1966) observed that, the synonyms of this species had been confused because of the identifications and names were based on small specimens. $C$. rotundatus (Proce) and C. oculatus (Gray) have not been recognized as conspecific with larger, more elongate specimens such as C. maculata (Bloch) C. willughbeii (Lay and Bennett) and C. longirostris (Tortonese). As the body length increases there is a proportional decrease in head length, eye diameter, body depth and first dorsal spine length and a proportional increase in length of the lobes of the anal and caudal fins which have not been considered while describing the above species.

It can be observed that the fin counts of $C$. maculata, C. willughbeii, C. rotundatus and C. villosus falls within a narrow range and cannot be used for differentiating between species (Table 1). Collections of Fedoryako (1981) consist of narrow length range except for $C$. maculata represented by a large sample, but smaller length groups. Berry and Baldwin (1966) and Matsuura (1981) observed that, the three species of Swainson (1839) i.e. Canthidermis angulosus (Quoy and Gaimard, 1825), Canthidermis gaimardii (Swainson, 1839) and Canthidermis oculatus (Gray, 1830) are synonyms of Canthidermis maculata (Bloch, 1786). They also established that Balistes maculata (Gmelin, 1789) and Balistes aureolus (Richardson, 1845) of Gunther (1870) is a synonym of Balistes maculatus (Bloch, 1786).
Observations made on Canthidermis maculata collected from west coast of India and Minicoy islands showed that three different colour patterns exists in the species. The regression analysis of morphometric measurements revealed a low relationship and insignificant, suggesting that Canthidermis maculata shows high degree of variability in case of body colour and certain morphological characters. Hence it may be concluded that C. willughbeii (Lay and Bennett, 1839), C. rotundatus (Proce, 1822), C. villosus Fedoryako, 1981 are probable junior synonym of $C$. maculata (Bloch, 1786).

\section{Acknowledgements}

The authors are grateful to Director, Central Marine Fisheries Research Institute, Cochin for the encouragement and facilities provided. The authors also wish to express sincere thanks to Rani Mary George, W. N. Eschmeyer, K. J. Abraham, Edwin Joseph, N. Rudramurty, Rosalie Shaffer, Cathy Schloss, Karine Fournier, for their support during the course of work. First author acknowledge the Marine Living Resources and Ecology- Ministry of Earth Sciences, Government of India, for the financial support.

\section{References}

Abdussamad, E. M., K. K. Joshi, P. U. Zacharia and K. Jayabalan. 2009. Emergence of triggerfishes (Family: Balistidae) as an alternate lucrative target fishery for trawls along the Tuticorin coast of Gulf of Mannar. Mar. Fish. Infor. Serv., T\& E Series, 199: 3-6.

Abraham, K. J., K. K. Joshi and V. S. R. Murty. 2011. Taxonomy of the fishes of the family Leiognathidae (Pisces, Teleostei) from the West coast of India, Zootaxa, 2886: 1-18.

Berry, F. H. and W. J. Baldwin. 1966. Triggerfishes (Balistidae) of the eastern Pacific. Proc. Califor. Acad. Sci., 34: 429-474.

Bleeker, P. 1866. Systema Balistidorum, Ostracionidorum, Gymnodontidorumque revisum. Neder. Tijdschr. Dierk., 3: 8-19.

Bloch, M. E. 1786. Naturgeschichte der ausländischen Fische. Berlin. 2: 160 pp.

Day, F. 1878. The fishes of India; being a natural history of the fishes known to inhabit the seas and fresh waters of India, Burma, and Ceylon. Fishes India (Part 4): 553779, William Dawson's, London.

Fedoryako, B. I. 1981. Triggerfishes of the genera Canthidermis and Xanthichthys (Balistidae, Tetraodontiformes) from the Indian and Pacific Oceans. Vopro. Ikhtiolo., 19: 983-995.

Fraser-Brunner, A. 1935. Notes on the Plectognath fishes.-I. A synopsis of the genera of the family Balistidae. Ann. Mag. Nat. Hist. Series, 15: 658-663.

Gmelin, J. F. 1789. Caroli a Linné. Systema Naturae per regna tria naturae, secundum classes, ordines, genera, species; cum characteribus, differentiis, synonymis, locis. Editio decimo tertia, aucta, reformata. 3 vols. in 9 parts. Lipsiae, 1788-93, 10331516.

Gray, J. E. 1830-35. Illustrations of Indian zoology; chiefly selected from the collection of Major-General Hardwicke, F.R.S.20 parts in 2 vols, 84-99.

Günther, A. 1870. Catalogue of the fishes in the British Museum. Catalogue of the Physostomi, containing the families Gymnotidae, Symbranchidae, Muraenidae, Pegasidae, and of the Lophobranchii, Plectognathi, Dipnoi, Leptocardii, in the British Museum, 8: 549 pp.

Hubbs, C. L. and K. F. Lagler. 1958. Guide to the fishes of the great lakes and tributary waters. Cranbrook. Inst. Sci. Bull., 18: 100 pp.

Jones. S and M. Kumaran. 1980. Fishes of the Laccadive Archipelago. Mathrubhumi press, Cochin, p. 662-676.

Lachner, E. A. and R. E. Jenkins. 1971. Systematics, distribution, and evolution of the chub genus Nocomis Girard (Pisces, Cyprinidae) of eastern United States, with descriptions of new species. Smithson. Contrib. Zool., 85: 1-97.

Lay, G. T., and E. T. Bennett. 1839. Fishes. p. 41-75, Pls. 15-23. In: The zoology of Captain Beechey's voyage. to the Pacific and Behring's Straits in 1825-28. 
Matsuura, K. 1980. A revision of Japanese balistoid fishes. I. Family Balistidae. Bull. Natl. Sci. Mus. Ser. A (Zoology), 6: 27-69.

Mitchill, S. L. 1815. The fishes of New York described and arranged. Trans. Liter. Philos. Soc. New York, 1: 355-492.

Moore, D. 1967. Triggerfishes (Balistidae) of the western Atlantic. Bull. Mar. Sci., 17: 689-722.

Procé, M. 1822. Sur plusieurs espèces nouvelles de poissons et de crustacés observées dans un voyage de France à Manille. Bulletin de la Société Philomathique de Paris, Science, p.129-134.

Quoy, J. R. C. and J. P. Gaimard. 1824-25. Description des Poissons. Chapter IX. In: Freycinet, L. de, Voyage autour du Monde. exécutésur les corvettes de L. M. "L'Uranie" et "La Physicienne," pendant les années, Paris, p.192-401.
Richardson, J. 1845. Ichthyology.-Part 3. In: R. B. Hinds (ed.) The zoology of the voyage of H. M. S. Sulphur, under the command of Captain Sir Edward Belcher, R. N., C. B., F. R. G. S., etc., during the years 1836-42, No. 10. Smith, Elder \& Co. London. p. $99-150$.

Smith, M. M. and P. C. Heemstra. 1986. Family No. 263: Balisitdae (876-882), In: Smith's Sea Fishes. Third impression, Macmillan, South Africa, Johannesberg, $1047 \mathrm{pp}$.

Snedeor, G. W. and W.G. Cochran. 1967. Statistical methods (6th edn). Oxford and IBH publishing Co. New Delhi, 250 pp.

Swainson, W. 1839. The natural history and classification of fishes, amphibians, \& reptiles, or monocardian animals. London, $448 \mathrm{pp}$. 